\title{
Safe implementation of index telephone clinic appointments for patients with suspected lower gastrointestinal cancer with concurrent financial and environmental benefits.
}

Kasun Wanigasooriya ${ }^{1}$, Diwakar Sarma ${ }^{1}$, Peter Woods $^{1}$, Paul O'Connor ${ }^{1}$, Adrian Matthews ${ }^{1}$, Muhammad Imran Aslam ${ }^{1}$, Carolyn Dando ${ }^{1}$, Henry Ferguson ${ }^{1}$, James Francombe ${ }^{1}$, Neeraj Lal ${ }^{1}$, Paul Murphy ${ }^{1}$, Trifonas Papettas ${ }^{1}$, Sean Ramcharan ${ }^{1}$, and Karen Busby $^{1}$

\section{${ }^{1}$ South Warwickshire NHS Foundation Trust}

June 21, 2021

\begin{abstract}
Aims: The COVID-19 pandemic led to hospitals in the United Kingdom substituting face-to-face (FtF) clinics with virtual clinic (VC) appointments. We evaluated the impact of virtual two-week wait (2-ww) lower gastrointestinal (LGI) consultations on stakeholders at a district general hospital in England. Methods: Patients undergoing index outpatient 2-ww LGI clinic assessment between 01/06/2019-31/10/2019 (FtF group) and 01/06/2020-31/10/2020 (VC group) were identified. Relevant data were obtained using electronic patient records. Compliance with national cancer waiting time targets (WTT) was assessed. Environmental and financial impact analyses were performed. Results: In total, 1531 patients were analysed (median age=70, male $=852,55.6 \%)$. Of these, $757(49.4 \%)$ were assessed virtually via telephone; the remainder were seen $\mathrm{FtF}(\mathrm{n}=774,50.6 \%)$. Ninety two $(6 \%, \mathrm{VC}=44, \mathrm{FtF}=48)$ patients had malignant pathology and 64 (4.2\%) had colorectal cancer (CRC); of these, $46(71.9 \%, \mathrm{VC}=26, \mathrm{FtF}=20)$ underwent treatment with curative intent. The median waiting times to index appointment, investigation and diagnosis were significantly lower following $\mathrm{VC}$ assessment $(\mathrm{p}<0.001)$. The cancer detection rates $(\mathrm{p}=0.749)$, treatments received $(\mathrm{p}=0.785)$ and median time to index treatment for CRC patients $(\mathrm{p}=0.156)$ were similar. A significantly higher proportion of patients were seen within two weeks of referral in the VC group $(\mathrm{p}<0.001)$. VC appointments saved patients a total of 9288 miles, 0.7 metric tonnes of CO2 emissions and $£ 7482.97$. Taxpayers saved $£ 80,242.00$ from VCs. No adverse events or complaints were reported in the VC group. Conclusion: Virtual 2-ww LGI clinics were effective, safe and were associated with tangible environmental and financial benefits for stakeholders.
\end{abstract}

\section{Hosted file}

Manuscript.docx available at https://authorea.com/users/405037/articles/527153-safeimplementation-of-index-telephone-clinic-appointments-for-patients-with-suspected-lowergastrointestinal-cancer-with-concurrent-financial-and-environmental-benefits

\section{Hosted file}

Table-2.docx available at https://authorea.com/users/405037/articles/527153-safeimplementation-of-index-telephone-clinic-appointments-for-patients-with-suspected-lowergastrointestinal-cancer-with-concurrent-financial-and-environmental-benefits

\section{Hosted file}

Table-1.docx available at https://authorea.com/users/405037/articles/527153-safeimplementation-of-index-telephone-clinic-appointments-for-patients-with-suspected-lower- 
gastrointestinal-cancer-with-concurrent-financial-and-environmental-benefits

\section{Hosted file}

Table-3.docx available at https://authorea.com/users/405037/articles/527153-safeimplementation-of-index-telephone-clinic-appointments-for-patients-with-suspected-lowergastrointestinal-cancer-with-concurrent-financial-and-environmental-benefits

\section{Hosted file}

Table-4.docx available at https://authorea.com/users/405037/articles/527153-safeimplementation-of-index-telephone-clinic-appointments-for-patients-with-suspected-lowergastrointestinal-cancer-with-concurrent-financial-and-environmental-benefits

\section{Hosted file}

Figure-1.docx available at https://authorea.com/users/405037/articles/527153-safeimplementation-of-index-telephone-clinic-appointments-for-patients-with-suspected-lowergastrointestinal-cancer-with-concurrent-financial-and-environmental-benefits

\section{Hosted file}

Figure-2.docx available at https://authorea.com/users/405037/articles/527153-safeimplementation-of-index-telephone-clinic-appointments-for-patients-with-suspected-lowergastrointestinal-cancer-with-concurrent-financial-and-environmental-benefits 